\title{
The Effect of Moon Phase on The Catch of Bigeye Tuna (Thunnus obesus) in Eastern Indian Ocean
}

\author{
Irwan Jatmiko ${ }^{1 *}$, Bram Setyadji ${ }^{1}$, and Rani Ekawaty² \\ ${ }^{1}$ Research Institute for Tuna Fisheries \\ JI. Mertasari 140, Sidakarya, Denpasar, Bali, Indonesia 80224 \\ ${ }^{2}$ Faculty of Marine and Fisheries, University of Udayana \\ Jl. Kampus Bukit Jimbaran, Badung, Bali, Indonesia 80361 \\ Email: irwan.jatmiko@gmail.com
}

\begin{abstract}
Tuna is one of the important export commodities to increase government income. One of economically important tuna species is bigeye tuna (Thunnus obesus) which has a proportion of $21 \%$ of the total production of large tuna group. The objective of this study was to investigate the effects of different moon phase on the catch of bigeye tuna (T. obesus) in Eastern Indian Ocean. Data collection was conducted by the scientific observers from August 2005 to June 2014 in the tuna longline vessels were based in the port of Benoa, Bali. Moon phase data were collected from August 2005 to June 2014 from National Aeronautics and Space Administration (NASA). Catch data were calculated using the catch rate formula which defined as the number of catches per 100 hooks. The number of catch rate then was sorted into each moon phases and were analyzed using one-way Anova. This study covered 62 trips and 1,480 numbers of operations or sets was conducted from sampled vessels. The result showed that the average catch rate of bigeye tuna differed significantly among the moon phases. Tukey post-hoc tests showed that the average catch rate at full moon was the highest among the groups with around 0.3/100 hooks. This study showed that moon phase had significant effect on the catch of bigeye tuna (T. obesus) that increased the catch during full moon.
\end{abstract}

Keywords: moon phase, catch rate, Eastern Indian Ocea, tuna, Thunnus obesus

\section{Introduction}

Tuna is known as one of export commodities of Indonesian government. Many species can be found in the area (Barata et al., 2011; Sala, 2012). The production of large tuna group reached more than 1.35 million tons in the period from 2004 to 2012 ,. One of the important tuna species is bigeye tuna (Thunnus obesus) which has a proportion of $21 \%$ of the total production of large tuna group during that time. This value was the second largest after yellowfin tuna (Thunnus albacares) with $72 \%$ (DGCF, 2014).

Bigeye tuna ( $T$. obesus) is a highly migratory species which spread from tropical to sub-tropical waters. This species can be found in almost big ocean in the world such as Atlantic Ocean, Pacific Ocean and Indian Ocean. In Indonesia, the distribution of bigeye tuna stretch from West Sumatera Waters, South Java Waters, Banda Sea and Sulawesi Sea to North Papua Water (Froese and Pauly, 2016).

With those potency, it is worthy if tuna become one important commodities in food sector. Moreover, Indonesian Government initiates to increase the fishermen welfare through the increase of capture production. This program is one of several actions in Economic Policy Package to intensify the economy and improving people's welfare (Asril and Akuntono, 2015). Additionally, Ministry of Fisheries and Marine Affairs had commenced the National Plan of Action (NPOA) for the management of tuna, skipjack and neritic tuna. This NPOA needs guideline in utilizing tuna resources and maintain their sustainability (DGCF, 2014).

In order to increase the number of catches, appropriate strategy in fishing operations need to be implemented. One of the strategies that can be use is conducting the operations by observing the moon phase. Many fishermen believe that moon phase 
influence fishing activity and the number of catch. The objective of this study was to investigate the effects of different moon phase on the catch of bigeye tuna ( $T$. obesus) in Eastern Indian Ocean.

\section{Material and Methods}

\section{Data collection}

Data collection was conducted from August 2005 to June 2014 in the tuna longline vessels based in the port of Benoa, Bali. Operation of longline tuna vessel per trip lasted from 3 weeks to 3 months. The form the number of bigeye tuna catch, total number of hooks per set and the position of fishing ground using Global Positioning System (GPS) were collected daily during the trip.

Sampling was done at area between 90-16० S and $109^{\circ}-120^{\circ} \mathrm{E}$ (Figure 1). This was applied to minimize the influence of different environmental conditions to the number of catches due to the different locations of fishing ground.

Moon phase data were collected from the same period from National Aeronautics and Space Administration (NASA) (Espenak, 2015). These data divided into four categories i.e. first quarter, full moon, last quarter and new moon. Full moon and new moon period refers to full moon and new moon day \pm 3 days. Whereas in between period days were pooled as first quarter or last quarter periods. Catch rate of bigeye tuna ( $T$. obesus) were sorted during these moon phases to evaluate the effect of moon phase on the catch of this species.

This study covered 62 trips and 1,480 numbers of operations or sets were conducted from sampled vessels. The highest number of trips occurred in 2006 with 10 trips. However, the highest number of setting occurred in 2008 with 276 sets. The total hooks are nearly 1.8 million hooks, thus it is around 180,000 hooks per year. The highest average number of hooks per set was 1,458 in 2005 and the lowest average number of hooks per set was 956 hooks in 2012 (Table 1).

\section{Data analysis}

Data were analysed using the catch rate formula which defined as the number of catches per 100 hooks. It means that the amount of catches counted in proportion to the number of the hooks per set. The number of catch rate then sorted into each moon phases and analyzed using one-way Anova. This analysis was conducted to compare the effect of different moon phase to the catch rate of bigeye tuna. Post hoc test were applied to confirm the differences occurred among groups. All statistical analysis was run using SPSS Statistics 20. The limitation of this study is only to compare the effect of moon phase. Other circumstances such as fishing gear and other oceanographic condition were considered to be the same.

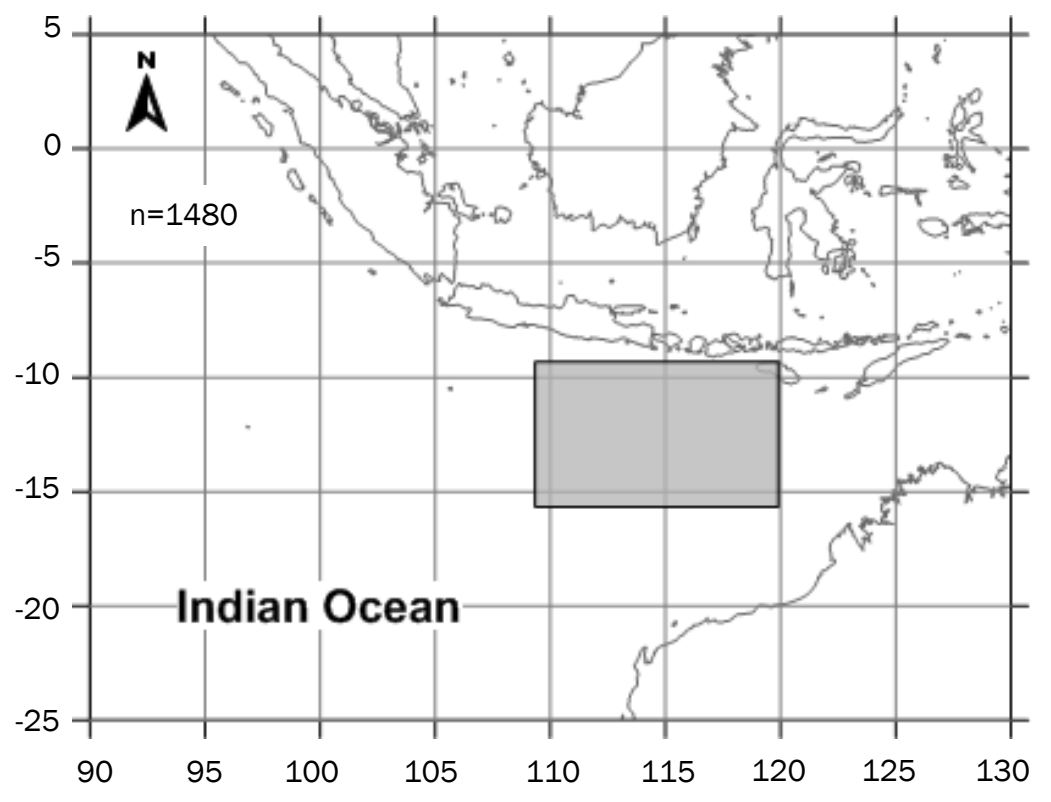

Figure 1. Fishing ground of sampled longline vessels. 


\section{Results and Discussion}

\section{Moon phase}

The condition of bigeye tuna stock in Indian Ocean is in good condition, not over fishing. Therefore, the production of this species can still be increased with considering its sustainability (IOTC, 2013; ISSF, 2013). Indonesian government, as a member of Indian Ocean Tuna Commission (IOTC) also has an obligation to play an active role in the management of this species in Indian Ocean. One of the steps to support this aim was conducting research and data collection to observe monitor tuna stock in Indonesian waters. Hence, the fishermen in Indonesia can utilize bigeye tuna resources without override its sustainability (FAO, 2012; DGCF, 2014).

In total there were different number of sets, total hooks and number of catches (Table 2). The result showed that the average catch rate of bigeye tuna differed significantly among the moon phases
$(P<0.05)$. The result of Tukey post-hoc tests showed that the average catch rate at full moon was the highest among the groups with around $0.3 / 100$ hooks. While the other moon phases (first quarter, last quarter and new moon) were around 0.2/100 hooks which not significantly different among them (Figure 2).

Study on the effect of moon phase on the catch of fisheries resources have been done in recent years. These studies proved that there was relationship between moon phase and the catchability of pelagic fishes (Akyol, 2013). Moreover, moon phase also considered to give an effect on the behavior, feeding habit, migratory pattern and spawning period of fish species (King, 2010).

This study is the first published account to investigate the effect of moon phase on the catch of bigeye tuna ( $T$. obesus) in Eastern Indian Ocean. However, there were several publications studied the effect of lunar cycle or moon phase on the catch

Table 1. Number of trip, number of settings, fishing ground and number of hooks per set of sampled longline vessels.

\begin{tabular}{ccccccccc}
\hline \multirow{2}{*}{ Year } & \multirow{2}{*}{$\begin{array}{c}\text { Number } \\
\text { of trips }\end{array}$} & $\begin{array}{c}\text { Number of } \\
\text { settings }\end{array}$ & \multicolumn{2}{c}{ Fishing ground } & \multicolumn{3}{c}{ Number of hooks per set } \\
\cline { 6 - 9 } & & Lat (oS) & Lon (o$)$ & Total & Average & Min & Max \\
\hline 2005 & 8 & 103 & $12-16$ & $107-116$ & 150,216 & 1,458 & 1,280 & 1,781 \\
2006 & 10 & 216 & $09-16$ & $109-118$ & 306,001 & 1,417 & 400 & 1,848 \\
2007 & 7 & 127 & $09-16$ & $107-115$ & 168,530 & 1,327 & 660 & 1,921 \\
2008 & 8 & 276 & $09-15$ & $109-119$ & 302,483 & 1,096 & 480 & 1,881 \\
2009 & 9 & 220 & $09-14$ & $111-119$ & 253,051 & 1,150 & 576 & 1,711 \\
2010 & 5 & 150 & $09-15$ & $110-120$ & 205,541 & 1,370 & 432 & 2,058 \\
2011 & 4 & 111 & $12-15$ & $115-120$ & 116,384 & 1,049 & 528 & 1,440 \\
2012 & 4 & 77 & $12-14$ & $113-119$ & 73,602 & 956 & 396 & 1,387 \\
2013 & 5 & 158 & $09-13$ & $115-120$ & 170,553 & 1,079 & 624 & 1,470 \\
2014 & 2 & 42 & $10-13$ & $112-120$ & 52,140 & 1,241 & 816 & 1,650 \\
\hline Total & 62 & 1480 & & & $1,798,501$ & & & \\
\hline
\end{tabular}

Table 2. Number of sets, total hooks and number of catches for each moon phases.

\begin{tabular}{cccc}
\hline Moon phase & Number of sets & Total hooks & Number of catches \\
\hline First quarter & 373 & 459,158 & 1,004 \\
Full moon & 350 & 425,874 & 1,264 \\
Last quarter & 400 & 484,694 & 1,038 \\
New moon & 357 & 428,775 & 866 \\
\hline
\end{tabular}




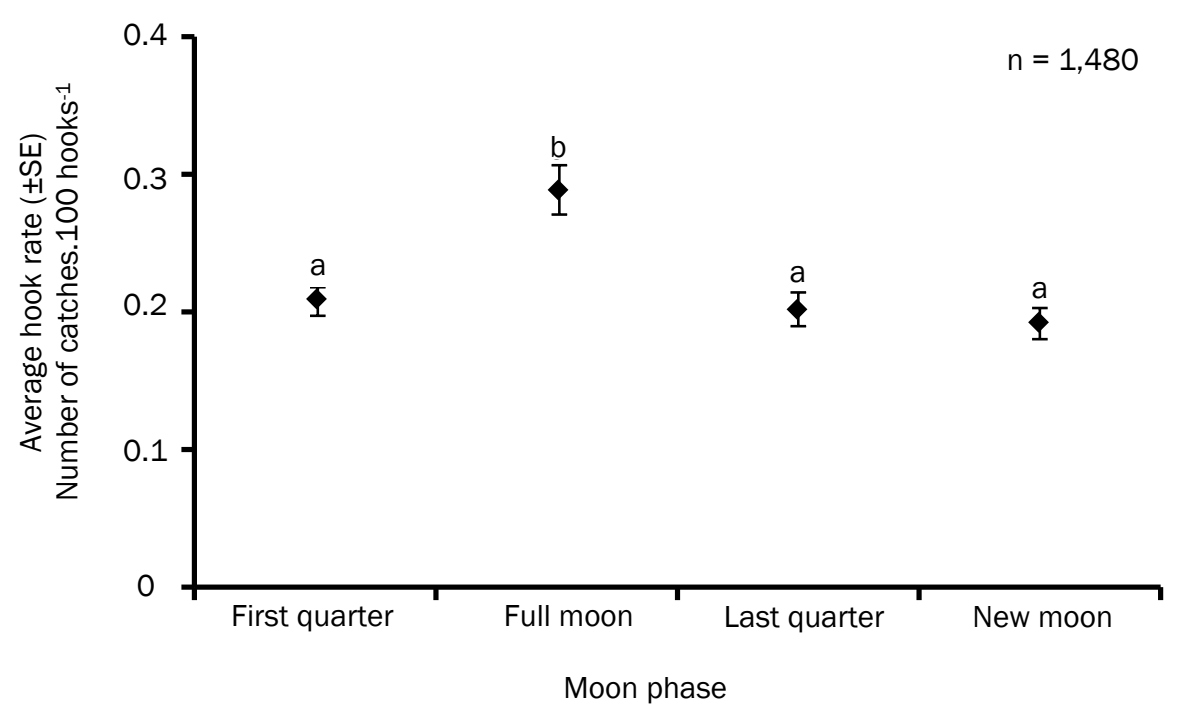

Figure 2. Average catch rate ( \pm SE) of bigeye tuna ( $T$. obesus) from each moon phase. The value with different letters showed statistically significant differences $(P<0.05)$.

Table 3. The effect of moon phase on the catch of pelagic species

\begin{tabular}{|c|c|c|c|c|}
\hline Species & Location & $\begin{array}{l}\text { Statistically } \\
\text { significant }\end{array}$ & Increase catch on & References \\
\hline Billfishes (Xiphiidae \& Istiophoridae) & Andaman Sea & yes & Full moon & Sajeevan (2013) \\
\hline Swordfish (Xiphias gladius) & Atlantic Ocean & yes & New moon & Akyol (2013) \\
\hline Albacore (Thunnus alalunga) & Atlantic Ocean & yes & New moon & $\begin{array}{c}\text { Akyol and Ceyhan } \\
(2012)\end{array}$ \\
\hline Albacore (Thunnus alalunga) & $\begin{array}{l}\text { Western Indian } \\
\text { Ocean }\end{array}$ & yes & Full moon & $\begin{array}{l}\text { Poisson et al. } \\
\quad(2010)\end{array}$ \\
\hline Swordfish (Xiphias gladius) & $\begin{array}{l}\text { Western Indian } \\
\text { Ocean }\end{array}$ & yes & First \& last quarter & $\begin{array}{l}\text { Poisson et al. } \\
\text { (2010) }\end{array}$ \\
\hline Striped marlin (Tetrapturus audax) & $\begin{array}{l}\text { North Pacific } \\
\text { Ocean }\end{array}$ & no & - & $\begin{array}{l}\text { Ortega-Garcia et } \\
\text { al. (2008) }\end{array}$ \\
\hline Bigeye tuna (Thunnus obesus) & $\begin{array}{l}\text { Eastern Indian } \\
\text { Ocean }\end{array}$ & yes & Full moon & Present study \\
\hline
\end{tabular}

of several pelagic species such as billfishes (Sajeevan, 2013), pelagic fish (Poisson et al., 2010) and striped marlin (Ortega-Garcia et al., 2008). This study showed significant increased on the catch of bigeye tuna in Eastern Indian Ocean during full moon. The same result occurred on billfishes in Andaman Sea (Sajeevan, 2013), swordfish (Xiphias gladius) and albacore (T. alalunga) in Western Indian Ocean (Poisson et al., 2010) where these fishes caught more during full moon.

The increase of fish catchability not only occurred during full moon. Other study showed that the fish catchability increased during new moon. As occurred in the albacore ( $T$. alalunga) (Akyol and Ceyhan, 2012) and swordfish (X. gladius) (Akyol,
2013) fishery in Atlantic Ocean. This target species for gillnet fishery obviously indicated the increasing of swordfish when close to new moon and reach the peak during new moon (Akyol, 2013).

Similar result also showed on the catch of swordfish in driftnet fishery in Italian Basin. The catch of this species increased twice during new moon compared to it during full moon. Furthermore, the catch of swordfish ( $X$. gladius) also increased significantly during first and last quarter during moon phase (Poisson et al., 2010). However, not all these studies showed the influence of moon phase on the fish catchability. Different result showed on the catch of striped marlin (Tetrapturus audax) in North Pacific Ocean. As one of the target species for 
sport fishing, the catch of striped marlin more influenced by weather condition rather than moon phase (Ortega-Garcia et al., 2008). The comparison of the effect of moon phase on the fish catches was shown in Table 3.

The result showed that fishing operation during full moon increased the catch of bigeye tuna. Therefore, the longline fishermen recommended conducting the operation during full moon. However, because longline fishing is long trip operation, that covered all the moon phases, it is suggested to modify the fishing gear and fishing strategy outside the full moon period. The modification can be change the length of the branch line and the length of float line. Besides that, the fishermen can change the bait into preferable one.

\section{Conclusion}

This study showed that moon phase had significant effect on the catch of bigeye tuna ( $T$. obesus). The catch rate of bigeye tuna increased during full moon. Therefore, longline tuna fishermen recommended conducting fishing operation during full moon. Beside that time, the fishermen suggested to modify the fishing gear and fishing strategy to increase their catch.

\section{Acknowledgement}

This study is funded by collaborative research between Research Centre for Fisheries Management and Conservation (RCFMC) and Australian Centre for International Agricultural Research (ACIAR) from 2005-2009, Research Institute for Marine Fisheries (RIMF) from 2010-2011 and Research Institute for Tuna Fisheries (RITF) from 2012-2014. The authors wish to thank all RITF scientific observers for their contribution in data collection.

\section{References}

Akyol, 0. 2013. The influence of the moon phase on the CPUEs of swordfish gillnet fishery in the Aegean Sea, Turkey. Turkish J. Fish. Aquatic Sci. 13:355-358. doi: 10.4194/1303-2712v13_2_18.

Akyol, O. \& T. Ceyhan. 2012. Moon phase's influence on CPUE of Turkish albacore gillnet fishery. Collect. Vol. Sci. Pap. ICCAT. 68(2):499-502
Asril S. \& Akuntono, I. 2015. Pemerintah Terbitkan Paket Ekonomi, Ini Poin-poin Utamanya. [http://bisniskeuangan.kompas.com/read/201 5/09/09/182042026/Pemerintah.Terbitkan.P aket.Ekonomi.Ini.Poin-poin.Utamanya]. Accessed on 9 September 2015.

Barata, A., Novianto, D. \& Bahtiar, A., 2012. Sebaran ikan tuna berdasarkan suhu dan kedalaman di Samudera Hindia. IImu Kelautan: Indonesian Journal of Marine Sciences, 16(3): 165-170.

DGCF (Directorate General Capture Fisheries). 2014. National Plan of Action: Tuna, Skipjack and Neritic Tuna, Management Plan of Indonesia:. Directorate General Capture Fisheries, Ministry of Fisheries and Marine Affairs, Jakarta, Indonesia.126 pp.

Espenak, F. 2015. NASA Eclipse Web Site. [http://eclipse.gsfc.nasa.gov/SKYCAL/SKYCAL. html?cal=2015\#skycal]. Accessed 10 August 2015.

FAO (Food and Agriculture Organization). 2012. The State of World Fisheries and Aquaculture 2012. FAO Fisheries and Aquaculture Department. Rome, Italy. $230 \mathrm{pp}$.

Froese, R. \& Pauly, D. Editors. 2016. FishBase. World Wide Web electronic publication. www.fishbase.org, version (01/2016). [http://www.fishbase.org/search.php]. Accessed 11 January 2016.

IOTC (Indian Ocean Tuna Commission). 2013. Report of the Fifteenth Session of the IOTC Working Party on Tropical Tunas. San Sebastian, Spain, 23-28 October 2013. 93 pp.

ISSF (International Seafood Sustainability Foundation) 2013. ISSF Tuna Stock Status Update, 2013(2): Status of the world fisheries for tuna. ISSF Technical Report 2013-04A. International Seafood Sustainability Foundation, Washington, D.C.,USA. 88 pp.

King, M. 2010. Fisheries Biology, Assessment and Management, Second Edition. Blackwell Publishing Ltd. Oxford, England.381 pp.

Ortega-Garcia, S., Ponce-Diaz G., O’Hara R. \& Merila, J. 2008. The relative importance of lunar phase and environmental conditions on striped marlin (Tetrapturus audax) catches in sport fishing. 
Fish. Res. 93:190-194. doi: 10.1016/j.fishers. 2008.04.005.

Poisson, F., J.C. Gaertner, M. Taquet, Durbec J.P. \& Bigelow, K 2010. Effects of lunar cycle and fishing operations on longline-caught pelagic fish: fishing performance, capture time, and survival of fish. Fish. Bull. 108:268-281.

Sala, R., 2012. Composition of Skipjack Tuna (Katsuwonus pelamis L) Taken by Commercial
Fishery from the Northeastern Waters of Indonesia. IImu Kelautan: Indonesian Journal of Marine Sciences, 14(4):207-214.

Sajeevan, M.K. 2013. Evaluation of the effect of lunar cycle, monsoon and spatial differences on billfishes. IOTC-2013-WPB11-20, 17 pp 